\title{
Ramming attacks, pedestrians, and the securitization of streets and urban public space: a case study of New York City
}

\author{
Paul Hess ${ }^{1} \cdot$ Sneha Mandhan ${ }^{2}$ \\ Accepted: 4 February 2022 / Published online: 7 March 2022 \\ (c) The Author(s), under exclusive licence to Springer Nature Limited 2022
}

\begin{abstract}
Over the last decade, vehicles have been used as weapons to target, kill, and injure pedestrians in cities such as London, New York, and Berlin. In response to these attacks, governments are implementing new policies and physical interventions to securitize pedestrian spaces. A previous wave of urban securitization hardened buildings against explosives delivered by vehicles, but ramming attacks, by using the vehicles themselves as weapons, challenge established ideas about relationships between pedestrians and automobility. In this paper, we explore the conceptual shifts that need to accompany planning and designing for security from vehicle-ramming attacks, as compared to traditional anti-terrorism efforts. Using New York City as a case study, we review the design strategies cities are using to prevent vehicle-ramming attacks, and consider the potential trade-offs between these securitization efforts, contemporary models of street design, and the everyday use of urban public spaces.
\end{abstract}

Keywords Security design $\cdot$ Public space $\cdot$ Pedestrian safety $\cdot$ Street design $\cdot$ New York City $\cdot$ Counterterrorism

\section{Introduction}

Vehicle-ramming attacks present a new threat to urban public spaces, raising questions around how governments can securitize them without radically altering people's daily lived experiences of cities (Burke 2018; Coaffee 2017). The use of vehicles to deliberately hit, injure, and kill pedestrians dates back to the mid-twentieth century, but their incidence has increased globally in the last decade as extremist groups have propagated ideas for 'lone wolf' attacks using simple objects such as knives and vehicles to spread terror (Jasiński 2018; Vehicles as Weapons of Terror 2017). ${ }^{1}$ Vehicle-ramming attacks have increased in the last decade, with at least 62 attacks in cities including London, New York, and Berlin, killing over 240 people and injuring more

Sneha Mandhan

sneha.mandhan@mail.utoronto.ca

Paul Hess

hess@geog.utoronto.ca

1 Department of Geography and Planning, University of Toronto, Toronto, Canada

2 Department of Geography and Planning, University of Toronto, Room 5047, Sidney Smith Hall, 100 St. George Street, Toronto, ON M5S 3G3, Canada than 1000 (Counter Extremism Project 2019; Jasiński 2018). Cities have responded by securitizing busy and symbolically important public spaces by placing temporary concrete barriers or more permanent crash-rated bollards, and occasionally with more comprehensive redesigns. Most interventions, however, have been ad hoc, without clearly articulated principles and strategies (Gelinas 2018). This raises questions of how cities are negotiating the potential conflict between protecting public space users from vehicle-ramming attacks and the openness, publicness, and accessibility that is essential to successful urban public spaces.

Current academic literature on vehicle-ramming attacks, and the security responses that have emerged in response to these attacks, is severely limited. There is also very limited literature that questions the connections between the legacy of crime-related security design and counterterrorism securitization. This paper fills these gaps by exploring the interconnected legacies of urban design for safety and security related to the risks of crime and terrorism, and urban design related to traffic safety. The authors begin by asking how vehicle-ramming attacks differ from other forms of terrorism that threaten urban spaces, and how cities can respond to these risks while maintaining the quality of public life that

\footnotetext{
${ }^{1}$ Israeli soldiers have long been targeted by ramming attacks in the occupied territories.
} 
open, public spaces support. New York City is used as a case study because of its history and leadership in developing anti-terrorist strategies and its responses to two ramming attacks in 2017, along with its leadership in contemporary street and public space design.

The paper begins by describing the contemporary phenomenon of vehicle ramming attacks in European and North American cities. ${ }^{2}$ It then explores some of the urban design antecedents to securitizing public spaces, and briefly presents the largely separate sphere of street design aimed at pedestrian safety and enhancing public space. The New York City case is then used to understand the ways securitization is largely drawing from the counterterrorism tradition in reshaping actual streets. The authors are sensitive to the real security concerns being addressed by the city but focus on street and public space design from a perspective of accessibility and openness. Through this paper, the authors argue for the integration of securitization strategies with pedestrian-safety programs and street redesign efforts aimed at reducing conflicts between active transportation modes and automobility - a connection that is currently not being made in the practice of urban design for security.

\section{Vehicle-ramming attacks: a unique threat?}

Historically, terrorists have used vehicles to deliver explosives to their targets. However, a 2016 attack on a Bastille Day parade in Nice, France marked a mass attack where the assailant used the vehicle itself as a weapon, driving a 20-ton truck along the crowed Promenade des Anglais, killing 86 and wounding 434 people (Counter Extremism Project 2019). The frequency and severity of such attacks has increased, with terrorists targeting high-pedestrian-volume areas and bike paths in cities such as London, Berlin, Barcelona, and New York. Due to their relative ease of implementation, these attacks are likely to continue (Shaver 2018).

Vehicle-ramming attacks present a unique challenge because: they are unpredictable; they use every day, readilyavailable vehicles as a weapon of terror; they target crowded pedestrian public spaces (soft targets) as opposed to symbolic political building sites (hard targets); and they further complicate the relationship between automobility and active transportation modes. Vehicle ramming is 'a cheap but extremely effective way of inducing fear, promoting an ideological message, or just simply wreaking destruction,' by converting a 'bland, everyday object' into a 'lethal, semistrategic weapon' (Miller and Hayward 2019, pp. 3-4). In most attacks, terrorists have driven cars, vans, or trucks into

\footnotetext{
$\overline{2}$ The authors do not consider terrorism-related threats in other parts of the world; a major limitation of the paper.
}

crowded, open pedestrian spaces such as sidewalks. Online publications from extremist organizations advocate for targeting areas that have high pedestrian volumes and low vehicle volumes, allow for high acceleration prior to impact, and are narrow (Corporate Risk Services 2019). Most recent attacks in Western cities have followed these strategies. For example, in December 2016 a man drove a truck into one of Berlin's pedestrian Christmas markets, killing 12 and wounding 56 , and two out of the three vehicle-ramming attacks in London have been on the sidewalks along bridges which are narrow and minimize escape routes (Counter Extremism Project 2019).

In response, cities have responded in ad hoc ways. Immediate responses have included protecting special events such as Christmas markets, sporting events, and parades through the temporary deployment of armed guards, concrete barriers, and blockade vehicles, such as buses and municipal utility vehicles. For example, within an hour of the news of the Berlin attack, the New York City Police Department positioned several armed guards and blockade vehicles at the entrances of Christmas markets at Union Square, Columbus Circle, and Bryant Park (Reporters 2018). Longer-term interventions have included the installation of crash-rated bollards, fences, concrete planters, and reinforced street furniture such as lamp posts and benches (Dangerfield 2018). Local authorities in cities such as London, Barcelona, and New York have begun the installation of barriers around several urban spaces that draw large crowds, such as sports arenas and public plazas (Kaleta 2018; Lazo 2018; Sawyer 2018). Proposals for implementing security strategies such as reinforced street furniture and reduction of straight, linear roads have also been suggested as longer-term ways of tackling vehicle-ramming threats but remain to be implemented (Coaffee 2017; GCDN 2018; Shaver 2018).

There is a plethora of policy documents (see Table 1) that prescribe the specifications for vehicle barriers such as bollards, including their placing and standards for their crash or impact-rating. However, most of these documents were developed for securing site perimeters from VehicleBorne Improvised Explosive Devices (VBIEDs) as a first layer of defense for buildings that were considered high risk (FEMA 430, Site and Urban Design for Security: Guidance against Potential Terrorist Attacks 2007). In contrast, vehicle-ramming attacks target the "urban body of the crowd" (Aradau 2015), creating new kinds of security concerns. The use of bollards can change the openness of public spaces by creating pinch points along sidewalks during evacuation or everyday use. For example, immediately after the 2017 attacks on the Westminster Bridge, the London Metropolitan Police placed new barriers and fences that forced pedestrians to funnel through narrow spaces and forced cyclists to ride closer to vehicles, putting them at increased risk for collision (Gelinas 2018). Such conflicts are a result of the 
Table 1 Inventory and analysis of primary policy documents for counterterrorism strategies in the United States and New York

\begin{tabular}{|c|c|c|}
\hline Author/agency & Name of publication & Year of publication \\
\hline $\begin{array}{l}\text { Federal Emergency Management Agency (FEMA) } \\
\text { US Department of Homeland Security (US DHS) } \\
\text { New York Police Department (NYPD) }\end{array}$ & $\begin{array}{l}\text { Risk Management Series } \\
\text { FEMA 430: Site and Urban Design for Security. Guidance } \\
\text { Against Potential Terrorist Attacks }\end{array}$ & December, 2007 \\
\hline $\begin{array}{l}\text { National Counter-Terrorism Center } \\
\text { US DHS } \\
\text { Federal Bureau of Investigation (FBI) }\end{array}$ & $\begin{array}{l}\text { First Responder's Toolbox: Planning and Preparedness Can } \\
\text { Promote an Effective Response to a Terrorist Attack at } \\
\text { Open-Access Events }\end{array}$ & March, 2018 \\
\hline US DHS & $\begin{array}{l}\text { Guide to Active Vehicle Barrier (AVB) Specification and } \\
\text { Selection Resources }\end{array}$ & 2014 \\
\hline National Capital Planning Commission (NCPC) & The National Capital Urban Design and Security Plan & $\begin{array}{l}\text { October, } 2002 \text { (with } \\
\text { November, } 2004 \\
\text { addendum) }\end{array}$ \\
\hline $\begin{array}{l}\text { G4S, Corporate Risk Services-British multinational secu- } \\
\text { rity services company }\end{array}$ & $\begin{array}{l}\text { Intelligence Bulletin-Vehicular Terrorism. The Threat } \\
\text { Behind the Wheel }\end{array}$ & 2017 \\
\hline $\begin{array}{l}\text { Office of Security Policy and Industry, Engagement Surface } \\
\text { Division-Highway and Motor Carrier Section } \\
\text { Transportation Security Administration, US DHS }\end{array}$ & $\begin{array}{l}\text { Vehicle Ramming Attacks } \\
\text { Threat Landscape, Indicators, and Countermeasures }\end{array}$ & May, 2017 \\
\hline $\begin{array}{l}\text { David Cooper, Transportation Security Administration, US } \\
\text { DHS }\end{array}$ & $\begin{array}{l}\text { Vehicle Ramming Attacks. Threat Landscape, Indicators, } \\
\text { and Countermeasures (presentation) }\end{array}$ & January, 2018 \\
\hline $\begin{array}{l}\text { Mr. McCaul, from the Committee on Homeland Security } \\
\text { (US DHS) }\end{array}$ & Vehicular Terrorism Prevention Act of 2018 Report & March, 2018 \\
\hline Global Counterterrorism Forum & $\begin{array}{l}\text { The GCTF Soft Target Protection Initiative. Antalya Memo- } \\
\text { randum on the Protection of Soft Targets in a Counterter- } \\
\text { rorism Context }\end{array}$ & 2017 \\
\hline NYPD & $\begin{array}{l}\text { Engineering Security. Protective Design for High Risk } \\
\text { Buildings }\end{array}$ & 2009 \\
\hline $\begin{array}{l}\text { New York State Division of Homeland Security and Emer- } \\
\text { gency Services }\end{array}$ & $\begin{array}{l}\text { Ten Years After 9/11. An Overview of New York State's } \\
\text { Homeland Security Accomplishments }\end{array}$ & 2011 \\
\hline
\end{tabular}

siloed operation of transportation-related urban planning and design, and urban design for counterterrorism.

These types of interventions also elicit questions about the impacts of fortressing public spaces. Highly securitized landscapes such as the National Mall in Washington DC and the Eiffel Tower in Paris have been heavily criticized for their seemingly disproportionate levels of security to risk and for spreading fear among urban inhabitants (Bird 2017; Grabar 2017). Other strategies such as banning vehicles from high-volume pedestrians areas could fundamentally alter the urban fabric and pose several new challenges associated with transportation and urban planning (Clarke 2017). There are new questions that emerge in the light of vehicle-ramming attacks - questions that did not necessarily apply to the counterterrorism of the 2000s where designing for security focused on keeping vehicles and explosive devices away from symbolic, built assets. This new type of attack requires a rethinking of the threat-a speeding vehicle — and the potential target - a public space occupied by pedestrian crowds. This paper, by connecting the long-standing legacy of using crime-related security design strategies with urban design for counterterrorism against VBIEDs, shows that there is a need to fundamentally rethink the way in which we securitize our public spaces in the light of new and emerging security threats.

\section{Designing for safety: Crime Prevention Through Environmental Design}

Ideas about securitizing streets and public spaces are not new. Within urban design, security design legacies include Jane Jacobs' ideas of 'eyes on the street' (1961), essentially a call for design that encourages territorial social control through the possibility of observation. Related ideas were developed in succeeding decades, including Crime Prevention through Environmental Design (CPTED) (Jeffery 1971), Defensible Space (Newman 1973), and the Broken Windows Theory (Wilson and Kelling 1982). These ideas influenced urban design throughout the US, with, for example, Newman's ideas receiving support from the US Department of Housing and Urban Development, and the US Department of Justice for use in public housing projects (Cozens and Love 2015).

Design strategies for crime prevention which defined the first generation of CPTED, include the following: 
- Territorial reinforcement through real and symbolic barriers to clearly demarcate private and semi-private spaces from public spaces;

- Natural (e.g., placement of windows), formal (e.g., police), and technological (e.g., deployment of cameras) surveillance;

- Social and physical mechanisms of access control;

- Programing and design cues that signify activities that are 'acceptable' or 'legitimate';

- Image management which, similar to the Broken Windows Theory, uses visual cues of care and stewardship; (Cozens and Love 2015).

These strategies were heavily criticized for being environmentally deterministic and second generation CPTED strategies more emphasized social and community interaction to reduce neighborhood crime (Cozens and Love 2015). Yet, physical design features rooted in CPTED ideas have endured and have been carried over to security design for counterterrorism (GCDN 2018). These include the creation of safety zones around buildings to demarcate private, surveilled, and protected territory through the use of physical barriers, surveillance technology, and guards which have also became closely affiliated with the security zones created around important buildings in the US to protect them from VBIEDs-zones that are criticized as being 'barren, sterile, and fortress-like' (Hollander and Whitfield 2005).

\section{Designing for anti-terrorist security: target hardening and urban securitization}

The process of securitization refers to the "transformation of governmental practices, techniques, and technologies from an emphasis upon disciplining a population to securing a population" (Deukmedjian 2013), and to the creation of a 'security landscape' which is "moulded by the occupancy and utilization of land dominated by security considerations and by the general security expressions of society that have accumulated during history" (Soffer and Minghi, as cited in Coaffee et al 2009b). Terrorism can be defined as "deliberately targeted surprise attacks on arbitrarily chosen civilians, designed to frighten other people" and terror is defined as "armed or brutal force against those who can be terrorized-i.e., who cannot fight back" (Keohane and Hewitt, as cited in Graham 2004). Decisions made by terrorists to select targets and weapons are often strategic (Boddy 2007) with attacks typically aimed at symbolic targets to cause psychological fear among civilians (Bugliarello 2003). These targets are often urban as cities provide a "target-rich environment—a complex interacting system of people, buildings, infrastructure...that, all together, define a city's way of life," and are "powerful symbols that embody the pride of a nation" (Bugliarello 2003).

Sociologist Ulrich Beck (2002) defines the concept of a 'world risk society' as one where we live in a world of uncontrollable risk, and we lack the language to describe that risk and hence the mechanisms to address it. He highlights the non-quantifiable nature of terrorism-related threats similar to Peter Marcuse's (2006) writings on 'existential insecurity' which involves the understanding of risks as being inherently uncertain. Anthropologist Setha M. Low (2006), in writing about New York, also highlights the paranoia, insecurity, and fear among urban residents following the $9 / 11$ attacks. In tackling these larger societal concerns around security, scholars highlight the importance of moving towards 'methodological cosmopolitanism,' arguing that the co-existence of diverse populations affects the fear of and the redefinition of 'others' in urban society (Beck 2002; Gaffikin et al. 2010; Low 2006). Policy documents emphasize the need for security responses to be 'proportionate' to the nature of the threat, prescribing formulae for measuring the level of risk and applying these to risk-tiering systems for the development of security strategies (Engineering Security. Protective Design for High Risk Buildings. 2009; FEMA 430, Site and Urban Design for Security: Guidance against Potential Terrorist Attacks 2007).

In the 1990s in the United States (US), after the Oklahoma City bombing, cities began extensive efforts to harden 'assets,' primarily important governmental buildings, to protect them from Vehicle-Borne Improvised Explosive Devices (VBIEDs), also known as Hostile Vehicles in policy literature (P. Cozens and Love 2015). These efforts were magnified and accelerated after the 9/11 attacks (Marcuse 2006). Subsequently, around the same time, the United Kingdom (UK) extended efforts towards protecting their urban cores through physical interventions and deployment of extensive surveillance technologies such as Close-Circuit Television (CCTV) cameras (Coaffee, Wood, et al., 2009). Various published case studies on cities such as New York, Washington DC, Los Angelos, San Francisco, Belfast, and London, highlight the creation of 'landscapes of defense' (GCDN 2018; Gold and Revill 2000).

As described in national, state, and local policy documents, common physical interventions for fortressing include creating standoff distances using bollards, steel posts, and other barriers; hardening buildings and infrastructure; and incorporating security measures into regulations including building codes (Boddy 2007; Coaffee 2013a; Farish 2004; Little 2004; Vale 2005). Some scholars also identify more invisible landscape interventions such as trees, concrete signs, urban furniture, and planters with the capacity to block trucks (Benton-Short 2007; Coaffee, et al. 2009a, b; Eisinger 2004; GCDN 2018). 
In her analysis of the Security Plan of 2002 for the National Mall in Washington DC, geographer BentonShort (2007) highlights the trends towards 'hypersecurity' through increased 'fortressing and bunkering' of highly emblematic spaces. She also raises questions about the impact of these securitization measures on the ownership of space and the symbolism of democracy embedded within this particular monumental landscape. Gaffikin et al. (2010) use the framework of the contested city to demonstrate the strategies employed by cities like Nicosia and Belfast to either reinforce the ethno-political contestations of space or attempt to integrate various social groups. Chambers and Andrews (2019), using the case of concrete barriers scattered throughout Melbourne, Australia in response to a vehicle-ramming attack in 2017 , highlight how security work exists in between 'something and nothing'-where politics dictates the need to do something (in this case, to install temporary bollards) in response to a threat, and how it is through 'doing nothing' - by 'sitting passively where they have been placed' - that the bollards prove effective ( $\mathrm{p}$. 1030). They also highlight the '\#bollart' movement which arose in response to the perceived ugliness of the concrete barriers-where communities came together in protest to beautify or 'soften' the appearance of the concrete barriers in a move to 'reclaim' the city (Chambers and Andrews 2019).

In addition to physical interventions, there are a series of technological interventions for surveillance, invoking the idea of the panopticon, that have also been implemented internationally. CCTV technology has existed and been widely deployed in many cities since the late 1900s. Additionally, newer technologies of crowd surveillance have recently emerged. Nishiyama (2018) explores some of the commercially available crowd surveillance technologies, such as the one developed by NEC Corporation, and its deployment in Tokyo. They highlight the growth in the development of practices aimed at crowd management to protect people in crowded urban environments. They outline the underlying basis of monitoring density and flow of crowd movements in specific places at specific times to define both 'normal' and 'abnormal' crowd behavior, where the crowd is symbolic of the urban life that needs to be secured (Nishiyama 2018). They also situate this technology within the contemporary global trend of using algorithms to calculate uncertainty which is defined by many scholars as being intangible (Beck 2002; Little 2004; Marcuse 2006). These new technologies will have significant impacts on the design of public spaces, especially those susceptible to crowding, in the future as crowded places become increasingly targeted by terrorists.

The need for security is clear, but there are potential tradeoffs including increased privatization and control over urban spaces that accompany security interventions. Scholars using case studies of New York and Washington, DC, for example, highlight how securitization can hinder protest and other democratic practices through the visible militarization of important public spaces. They also argue that security measures legitimize limitations on public space use in the name of security, and create a 'politics of memory,' making visible the power of those responsible (Benton-Short 2007; Marcuse 2006; Németh and Hollander 2010). These efforts are also imposed through top-down processes without public participation (Benton-Short 2007; Bugliarello, 2005; Eisinger 2004). This trend is further inscribed by the increasing use of private actors in the deployment and operation of security (Coaffee 2013b; Németh and Hollander 2010), and the even more direct privatization of public spaces in the name of security (Low 2006; Marcuse 2006). How these concerns play out in particularly open, accessible public spaces such as sidewalks, where vehicle-ramming attacks may take place, is not addressed in academic literature.

These calls for proportionality of response to risk have informed much of the policy narrative since the 9/11 attacks in the US. However, the legacy of securitization, especially of building assets, dates back to the Cold War era where dispersed geographies and bunkers were a predominant response to the threat of bombing (Farish 2004). As outlined in the previous section, the lineage of strategies used for anti-terrorist target hardening can be traced back to CPTED ideas developed in the 1970s. The creation of security zones to demarcate territory, extensive surveillance, site access control, and extensive target hardening, are all techniques that were used for crime prevention prior to being adopted for anti-terrorism design. There are, however, critical differences between crime-related threats and terrorism-related threats. For example, while crime often targets individuals, terrorism targets groups of civilians, key infrastructure, or 'assets' that are often politically, economically, or socially symbolic (Savitch 2008). Additionally, these techniques effectively protect hard targets-important political, economic, and cultural building sites. However, pedestrians and vehicles are ubiquitous parts of the urban landscape. When the target is as omnipresent as a crowd of pedestrians, such target hardening measures are harder to implement and are less effective. In such cases, it is important to think beyond traditional anti-terrorism design and engage in questions around how interactions between pedestrians and automobiles are managed through overlap between transportation planning and counterterrorism-related security design. 


\section{Pedestrian-safety programs: conflicts between automobiles and active transportation modes}

A quite separate trajectory of urban design has been engaged in managing the relationship between pedestrians and vehicles. Modernist urban design and planning sought to separate motor vehicles and pedestrians at various scales, from the codification of sidewalk dimensions, and the regulation of pedestrian behavior in the late-nineteenth and earlytwentieth centuries (Ishaque and Noland 2006), to the creation of formal street hierarchies, with highways and arterials designed almost exclusively around moving traffic and local streets being organized around neighborhoods, from the depression era on (Hebbert 2005; P. M. Hess 2009). These strategies were intended to improve pedestrian safety as traffic volumes increased, but typically operated within a design frame that maximized the free movement of vehicles while limiting their interaction with pedestrians.

By the 1960s, Jane Jacobs and others began to critique such modernist street design as hostile to pedestrians and urban street life, but reform came slowly. In North America, 'traffic calming' with physical design elements such as speed humps, chicanes, and diverters to slow down motor vehicles and increase pedestrian safety began in the 1970s but only became well established for urban residential streets in the 1990s. Only in the early 2000s was traffic calming tentatively applied to larger streets through strategies such as mid-block crossings and refuge islands (P. Hess et al. 2019). Since then, change has been more rapid with several jurisdictions at all levels of government adopting "complete streets' policies to promote safe travel for users of 'all abilities' and 'all ages' including pedestrians and cyclists. Likewise, Vision Zero policies and programs that (at least rhetorically) seek to eliminate deaths and series traffic injures have also spread rapidly across North American cities in the last decade. A wide range of strategies are used including education and traffic regulation enforcement but changing engineering geometrics and street design to slow traffic and create better pedestrian and cycling facilities is integral to the approach.

Some cities, with New York being a leader, are also now reallocating roadway space previously devoted to motor vehicles to create new facilities and spaces for bicycles and pedestrians. New York's achievements include a network of newly separated cycle lanes, a series of pedestrian plazas, and the pedestrianization of Times Square (Sadik-Khan and Solomonow 2017). The city has also pioneered street design guidelines promoting pedestrian- and cycling-oriented redesigns and has a Vision Zero program that is a model for other cities. New street design aimed at creating safe streets for pedestrians and increasing public space, however, has been developed in relation to issues of general automobility quite separately from efforts to securitize buildings and public spaces from terrorist attack. A large part of this separation has been due to the siloed nature of urban policy-making where safety is dealt with as part of transportation planning, and security is tackled as part of crime and terrorism prevention efforts. This paper presents a rationale for these connected traditions to come together in the face of the threat of using vehicles as weapons.

\section{Case study: designing for security and safety in New York City}

Since the 9/11 attacks, New York has been a North American leader on counterterrorism policy and security planning. New York experienced its first vehicle-ramming attack in May 2017, when a man drove into pedestrians in Times Square, killing one and injuring 22 before crashing into a bollard (Rosenberg and Stack 2017). Although not considered terrorism, the attack was purposeful and created concern for securitizing busy public spaces. A second attack occurred in October 2017, when a man deliberately drove a rented truck on to a major bike path in Lower Manhattan, killing eight and injuring 12 people (Counter Extremism Project 2019). The city has since embarked on an expanded effort to install bollards, concrete blocks, and other physical barriers around the peripheries of many high-profile public spaces.

Here, the authors begin to evaluate these securitization efforts, especially in terms of the strategies being developed, and their impact on pedestrian and public spaces. They use New York's policies, information from interviews with public officials and public space advocates (carried out between July and November, 2019), and site visits to securitized spaces (conducted during July and August, 2019) to inform the case study. ${ }^{3}$ Semi-structured interviews, including questions around what efforts had been and were being undertaken to securitize public spaces from vehicle-ramming attacks in the city and what policy resources were being used for the site identification and security design process, were conducted with representatives from the following agencies:

\footnotetext{
${ }^{3}$ Further interviews with other stakeholders and site visits scheduled for the spring of 2020 were canceled due to the global COVID-19 pandemic, which has also severely affected the use and conception of public spaces in cities, both from a design perspective and from a use perspective. For example, cities all over the world have implemented initiatives for outdoor dining in curbside parking spaces which further complicate many of the arguments made in this paper. At the same time, cities have limited vehicular use on urban streets to promote pedestrian use and activity with safe physical distancing measures, which further complicates the notions around separation of vehicles and pedestrians on city streets.
} 
- The New York City Department of City Planning (DCP)

- The New York City Public Design Commission (PDC)

- The New York City Department of Transportation (DOT)

- The New York City Police Department's (NYPD) Counter-terrorism Bureau

- The New York Street Vendor Project (SVP)

Interviewees are identified by agency acronym. The New York City Department of Design and Construction, a capital agency that is responsible for many public construction projects, refused an interview, likely because of sensitivity of security concerns. Although the authors are interested in street and public space design from a perspective of accessibility and openness, they do not intend to downplay the very real security concerns being addressed by the City.

\section{Policy and administration}

Currently, NYC does not have a publicly-available policy or guideline document for protecting open public spaces from vehicle-ramming attacks. The PDC, responsible for design review of projects on City-owned property, is working on a best-practices document with examples from other cities globally but does not feel they have enough information to develop prescriptive guidelines (PDC). Currently, design guidance is garnered from documents such as U.S. General Services Administration's "The Site Security Design Guide" (2007), the Federal Emergency Management Agency's (FEMA) "Site and Urban Design for Security: Guidance against Potential Terrorist Attacks" (2007), and the National Capital Planning Commission's (NCPC) "The National Capital Urban Design and Security Plan" (2002).

Such external documents tend to be short statements of principals or are focused on protecting buildings from VBIEDs and do not relate to protecting pedestrians or other vulnerable road users. Only a few emphasize design, esthetics, and livability. The NCPC plan, for example, states that 'The Plan reflects our strong conviction that we can have both good urban design and good security' (iii), but is then focused primarily on standoff distances and building protection. These approaches tend to promote buildings floating in security zones which are disconnected from streets (Vale 2005). All the interview participants desired better guidance.

The 2016 Nice and Berlin vehicle-ramming attacks worked as 'a wake-up call' for the City to pay attention to broad public space securitization beyond buildings (NYPD). The 2017 attacks accelerated these efforts at which time the City immediately placed concrete blocks at various locations. In January 2018, Mayor de Blasio announced that the City would spend 50 million USD to secure high-risk public spaces including the installation of 1500 bollards (Goldstein 2018; Toure 2017). This effort is underway, with many of the city's best-known public spaces currently undergoing design retrofits. The Mayor's office coordinates these efforts through an Interagency Security Infrastructure Working Group that has existed since 9/11 (DCP, PDC). As an example of coordination, the working group manages the demand for concrete blocks throughout the city, with various agencies each controlling a limited number that must be 'choregraphed and coordinated' between locations and events (PDC).

\section{Selection of public spaces for securitization}

Previous to 2017, physical securitization was oriented towards VBIEDs. Since then, however, the NYPD CounterTerrorism Bureau has also taken the lead in identifying sites to protect against ramming attacks based on their having large pedestrian volumes and being high-profile or 'iconic' sites. The NYPD did note that they closely follow terrorist tactics to inform decision-making and use foreign intelligence information for site selection.

Figure 1 shows securitized sites in Manhattan identified by the DCP including public plazas such as Times Square and Penn Plaza, sidewalks such as around St. Patrick's Cathedral and near the Brooklyn Bridge (Fig. 2), bike paths including the West Street Bikeway (Fig. 2), and parks such as Central Park. This is not a complete list and additional sites are under consideration. The NYPD did suggest that although Manhattan has many securitized sites, they look for sites in every borough, as each 'has its own hot spots' (NYPD). The authors used this list of securitized sites (as shown in Fig. 1) for site visits, during which they documented physical design interventions aimed at increasing site security, especially along the perimeters.

\section{Designing for security from vehicle-ramming attacks}

The two standard securitization treatments in New York are concrete blocks and bollards. The city used blocks to secure sites immediately after the 2017 ramming attacks and continues to do so, both for temporary events, and as 'place holders' for permanent barrier installation (DCP), although some installations have been in place for a few years without any clear schedule for replacement. These installations are generally considered to be unattractive, with objection from some property owners, Business Improvements Districts (BIDs), and design-advocacy groups (DCP). Unlike permanent bollards, they do not go through a capital procurement process that includes public engagement. In some cases, there have been attempts to improve their appearance. For example, BIDs along the Broadway pedestrian plazas are using branded covers (Fig. 3), and blocks at the entrances to Rockefeller Center are contained within planter boxes (Fig. 3). The authors also observed more stylized concrete 
Fig. 1 Selected securitized sites in Manhattan
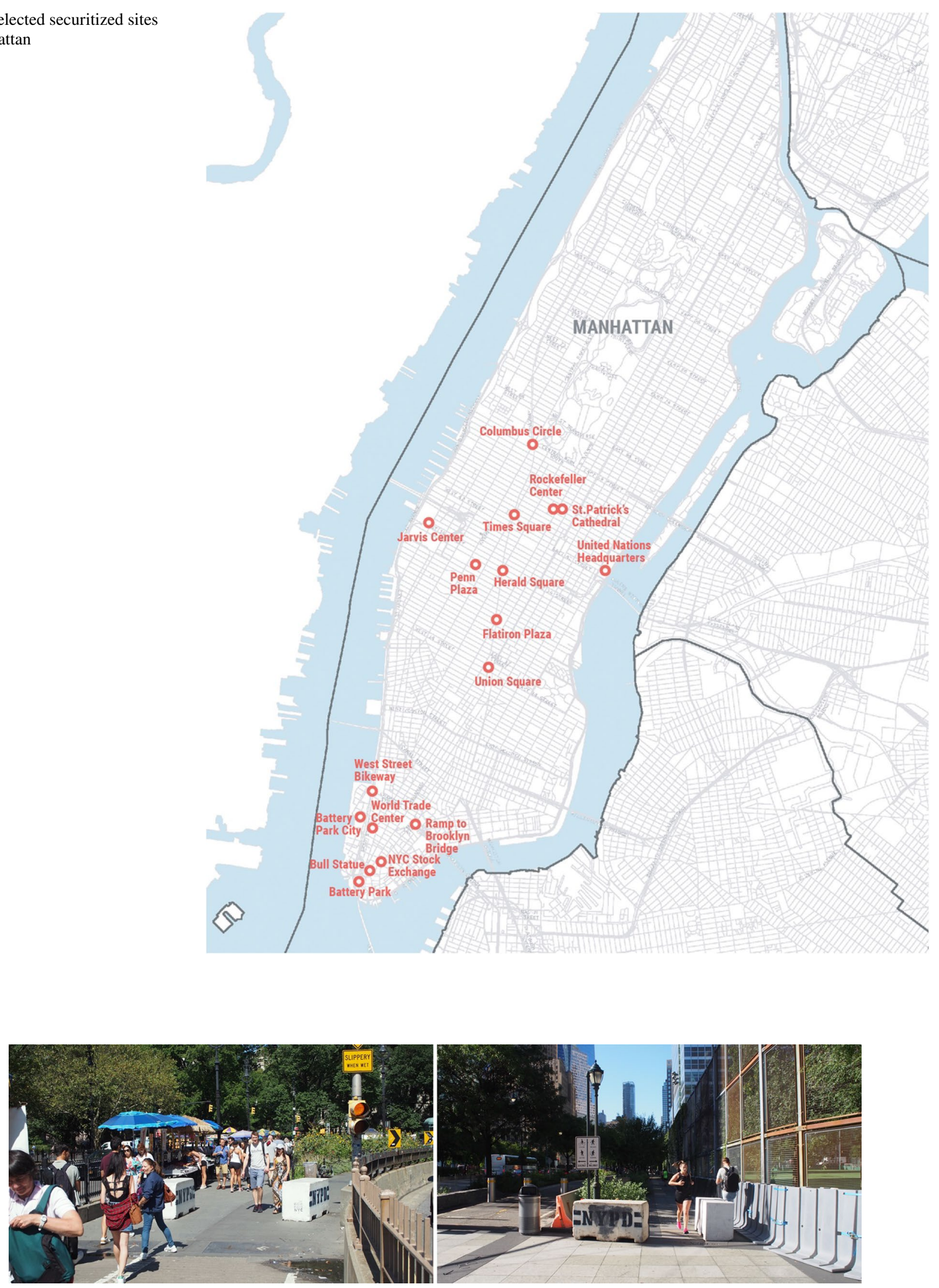

Fig. 2 Concrete blocks at entrance to the Brooklyn Bridge (left) and walkway parallel to the bollard-protected West Street bikeway (right) 售: 

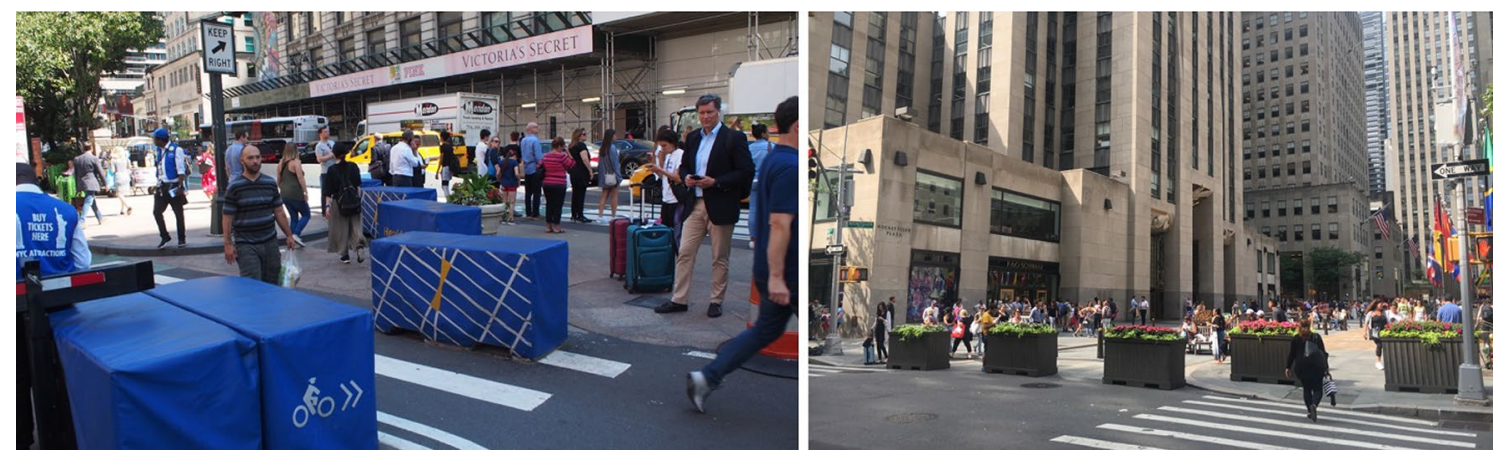

Fig. 3 Covered concrete blocks, Herald Square BID (left), and planters at Rockefeller Center (right)

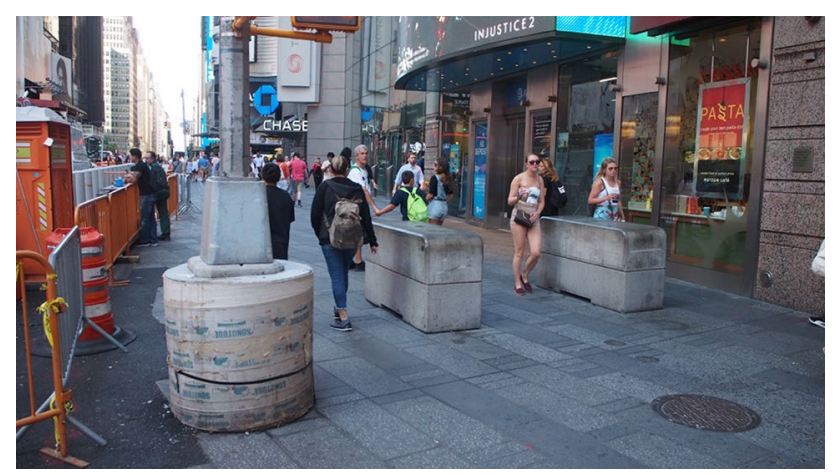

Fig. 4 Stylized blocks in Times Square (left) with bollards being installed on the left side of the photo

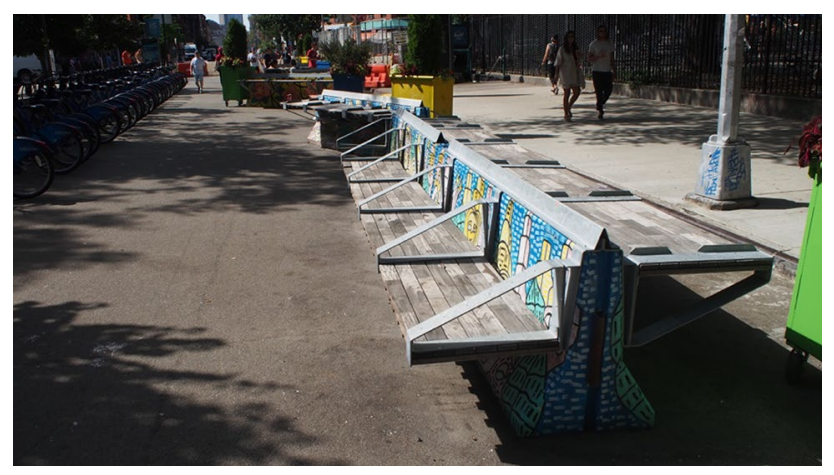

Fig. 5 Jersey barriers outfitted as benches and tables, Canal Street in Lower East Side/Chinatown

blocks in Times Square (Fig. 4), Union Square, and on Canal Street by Seward Park (Fig. 5).

The city's default strategy for permanently securitizing sites is with crash-rated bollards, a strategy included in pedestrian-safety design for decades (Figs. 6-7). The city uses pre-existing guidelines and regulations that specify the selection of bollards, their placement, and installation processes (DCP). Bollards have 'K-ratings' based on stopping a 15,000 -pound truck impacting at 30,40 , or 50 miles per hour (Reliance Foundry 2017). Such bollards were developed to stop VBIEDs, and there is debate over whether such 'severe' applications are needed in all securitized public spaces (DCP).

As with concrete blocks, the interviewees consider bollards to be unattractive. The PDC and NYPD, for example, noted that they are looking for alternative measures such as street furniture and landscaping strategies that can 'blend in and enhance' as well as protect, but are limited due to space constraints (PDC). At the curb line, particularly, it is not clear how to negotiate the installation of bollards with fire hydrants, bike-share stations, street furniture, vendor locations, etc. (DCP). There is also limited availability of standardized crash-rated street furniture from vendors.

The City is exploring other methods of controlling vehicle access such as special gates and retractable bollards, but these are expensive and not developed enough to provide practical solutions (DOT). Other, more singular design installations include the security zone created around the New York Stock Exchange (NYSE) after 9/11 with highly sculptural bronze blocks placed across sidewalks, landscapecovered trenches ('tiger traps'), and turntables (Fig. 8); crash-rated benches used by the Battery Park City Authority; and large barriers in Times Square that separate the roadway from pedestrian areas and also act as seating (Fig. 9). Not all of these have been successful. The NYSE turntables, for example, have faced several maintenance challenges and have been replaced by more conventional strategies (DCP). These urban design efforts have also been involved and resource-heavy, thus being limited to a handful of sites. In general, concrete blocks and bollards remain the standard approach for most sites in New York, especially when rapid and/or temporary response is needed.

While largely similar, some key differences can be noted between the securitization processes and approaches taken for the two projects described above. The NYSE project entailed extensive design of street furniture that was specific to protecting a hard asset (the NYSE building) by restricting potential impact by VBIEDs in the wake of the $9 / 11$ 


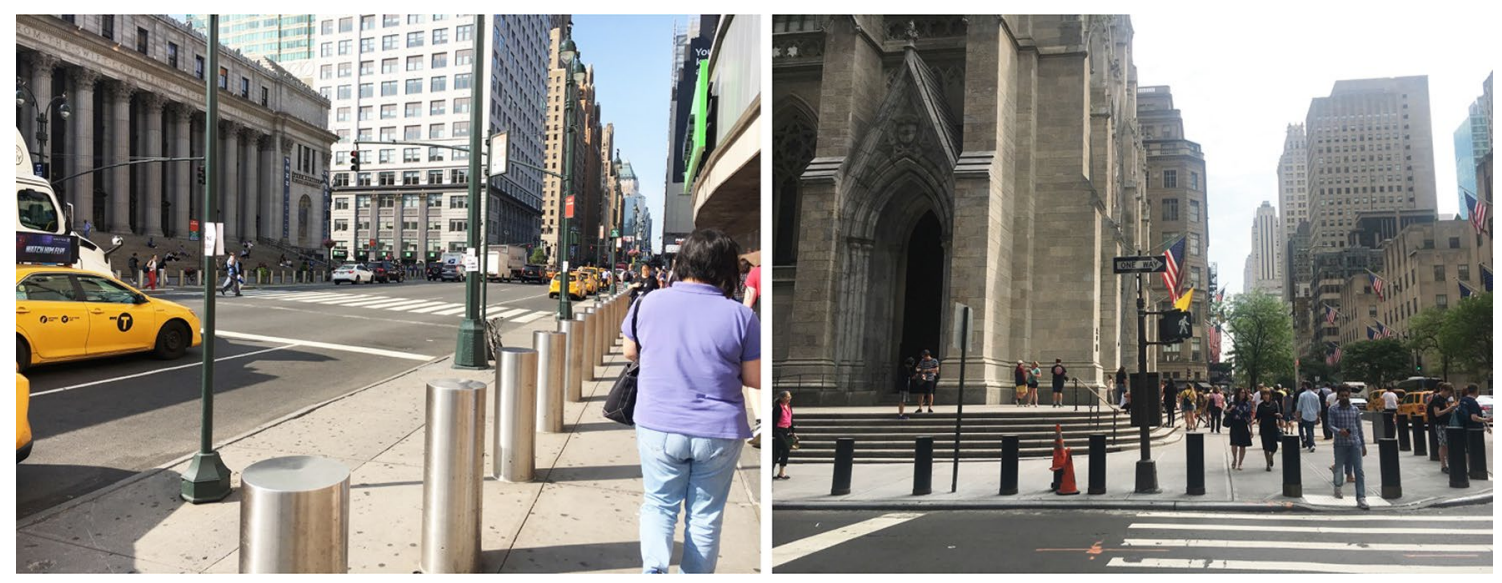

Fig. 6 K-rated bollards at Penn Station (left) and St.Patrick's Cathedral (right)
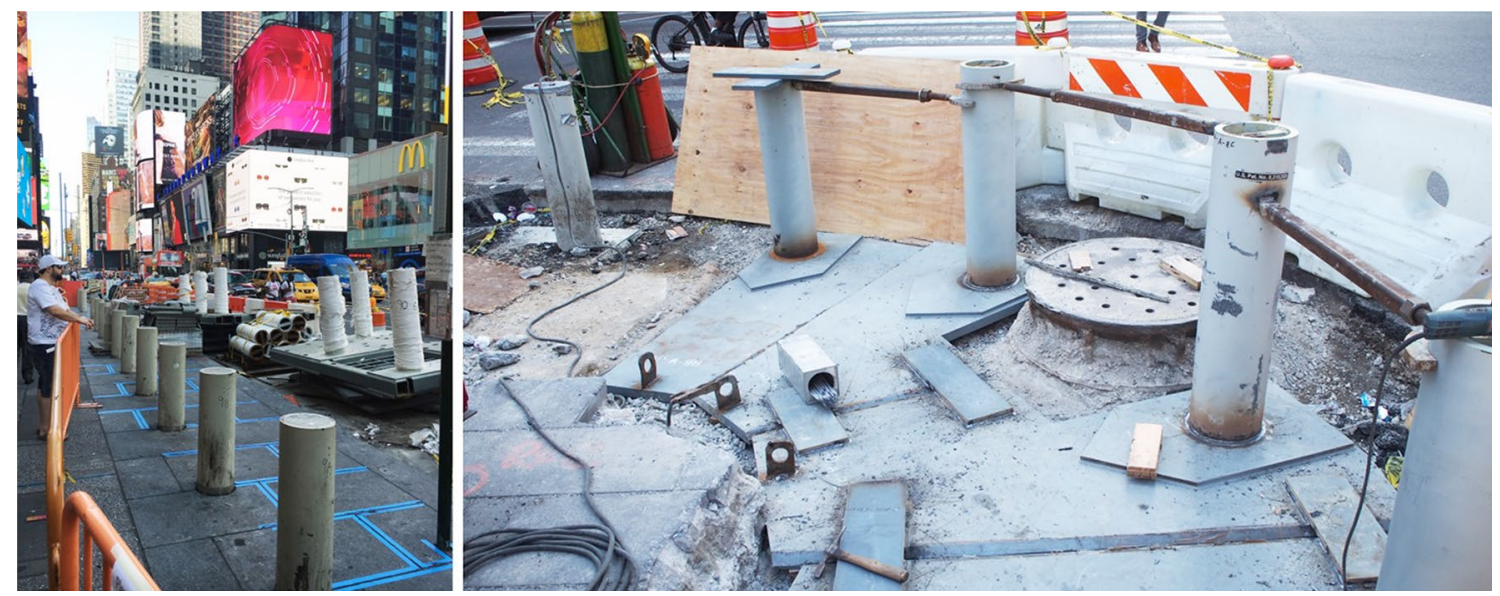

Fig. 7 Robust, k-rated bollards being installed, Times Square

attack, while providing some consideration for esthetics and urban design. The Times Square redevelopment, however, is essentially a pedestrian-safety project which takes a more comprehensive urban design approach to separating pedestrians and vehicles. It provides for safety and security of pedestrians within the landscape itself. While Times Square offers a good case study to understand how various agencies can work together to embed security from vehicle-ramming attacks into the urban landscape, there are several concerns about the redesign that need to be considered further. These are outlined in the next section.

\section{Security, safety, and publicness}

Academic research on securitization highlights how physical barriers are used to create security zones which foster fear and feelings of insecurity that are disproportionately large compared to the actual risk of an attack or accident (Beck 2002; Marcuse 2006). These spaces, due to the partial impediments to access, presence of security personnel (during certain times), and partial restrictions to movement, also reduce the level of openness of public spaces (Németh and Hollander 2010). The publicness of securitized spaces was also raised as a concern in the interviews, although responses from public officials were tempered and avoided direct criticism. Respondents from the PDC, for instance, stated that they have pushed for solutions that does not make the city 'feel like a fortress' or as 'excessively controlled,' which would impact 'the purpose of public space.' While they noted that risk must be considered, they also suggested that some BIDs worried about how the security measures put in place after 9/11 impacted the 'openness' and 'vitality' of their districts. The respondent from the DCP also said interventions can create 'a bit of discomfort,' but that this needs to be weighed against risks. The respondent from the DOT mentioned concern for over-application of bollards 'spreading fear,' and pointed to some criticism in the press that the 'hardening of our streets' was 'unwelcoming.' The NYPD 

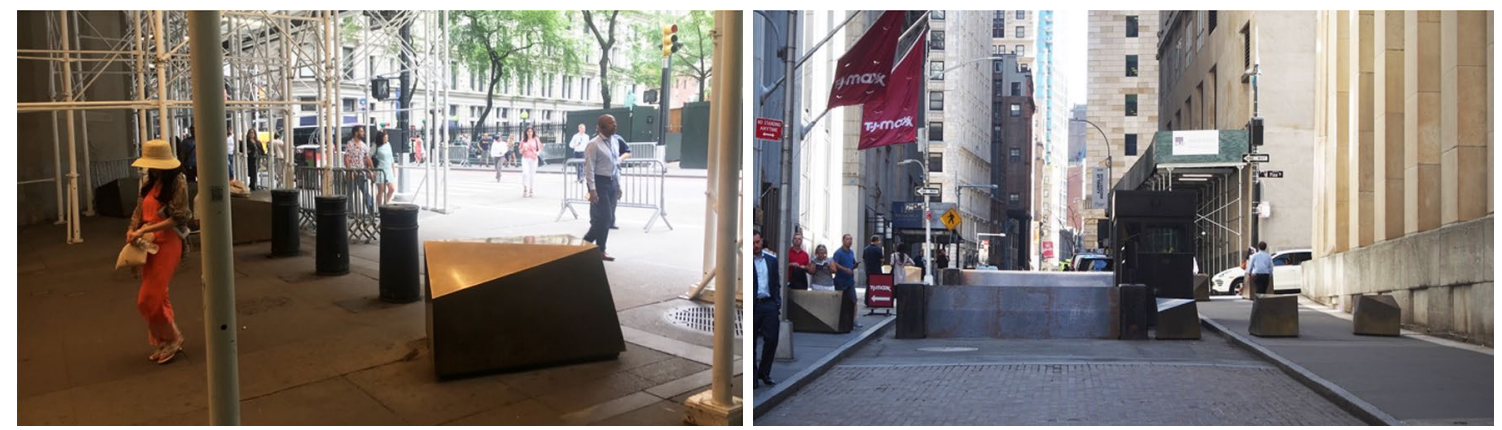

Fig. 8 NYSE site bronze blocks on Wall St (left), and wedge barrier with guardhouse at Pine and Nassau Street
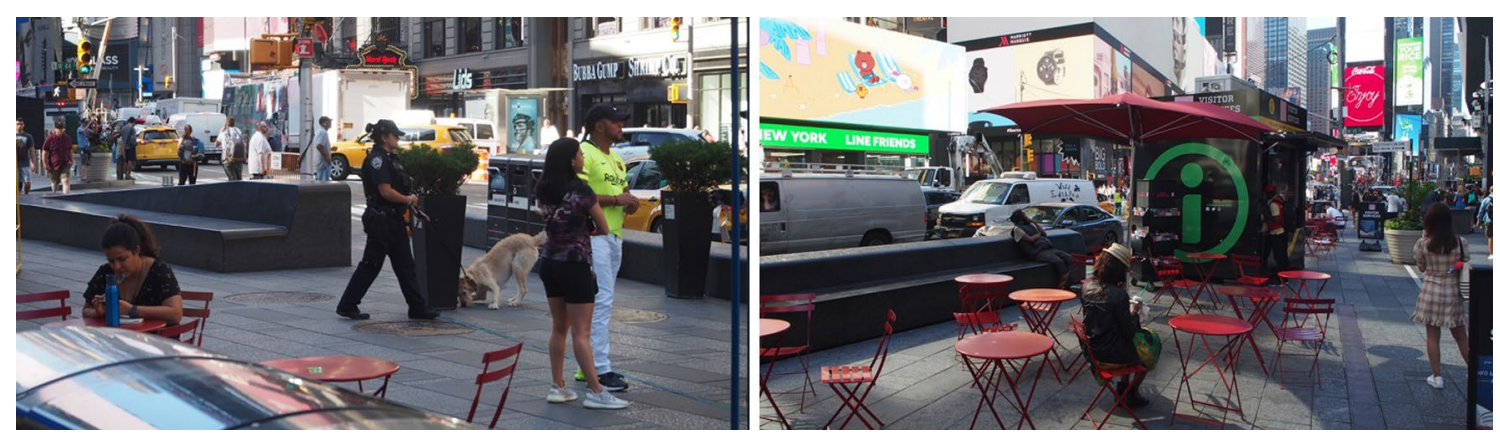

Fig. 9 Large barriers acting as street furniture, Times Square

was most positive, stating that while they understood there were issues of esthetics, they 'are not trying make people feel uncomfortable,' but, rather, wanted people to be able to gather in public places without worrying about security issues.

The interviewees were also asked about accessibility issues for disabled people, bottlenecks created given NYC's large pedestrian flows, or other issues of constrained use and accessibility. A general response was that bollard spacing conforms to the Americans with Disabilities Act. The respondent from the DCP did note that securitization measures create some 'constraint of the pedestrian clear path [that] has presented some definite issues.' The NYPD respondent noted that video analysis of people leaving Penn Station suggested that disabled people did not have 'any real struggle' negotiating bollards, and the DCP respondent commented that securitization at Madison Square has actually improved accessibility for sight-impaired people by creating better defined borders around the pedestrian plaza. The respondent from the NYPD stated, 'a bollard in itself has no major impediment to pedestrian flow,' citing work from the United Kingdom's Centre for the Protection of National Infrastructure (CPNI, 2014). They further suggested bollards could help pedestrian flow in crowded places because they help people queue, noting 'we never have really seen anyone walk into a bollard' (NYPD).

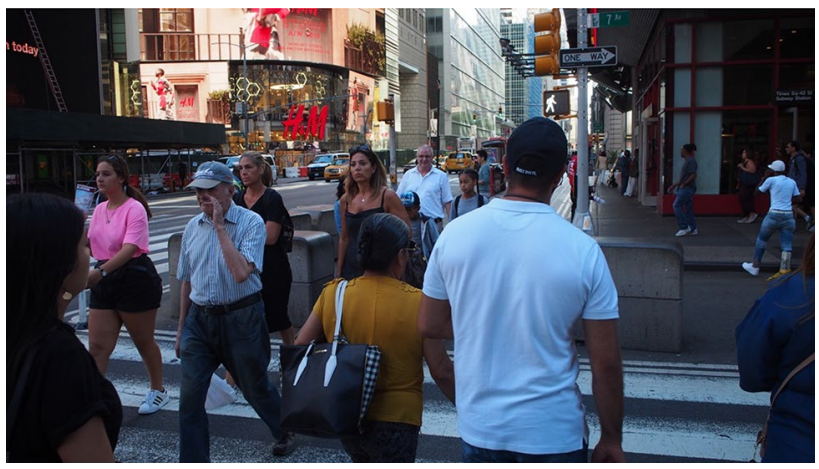

Fig. 10 Pedestrians crossing 42nd Street at 7th Avenue negotiating blocks

Based on limited observations by the authors, however, bollards and blocks constrain movement in at least some contexts. At crowed intersections, for example, NYC often experiences large platoons of crossing pedestrians, but blocks force people to pass through constrained openings (Fig. 10). Construction and other blockages also create tight spaces, where blocks further disrupt flows (Fig. 11). Additionally, literature on the experience of differentlyabled groups points to an increased level of discomfort due to sidewalk impediments such as concrete posts and 


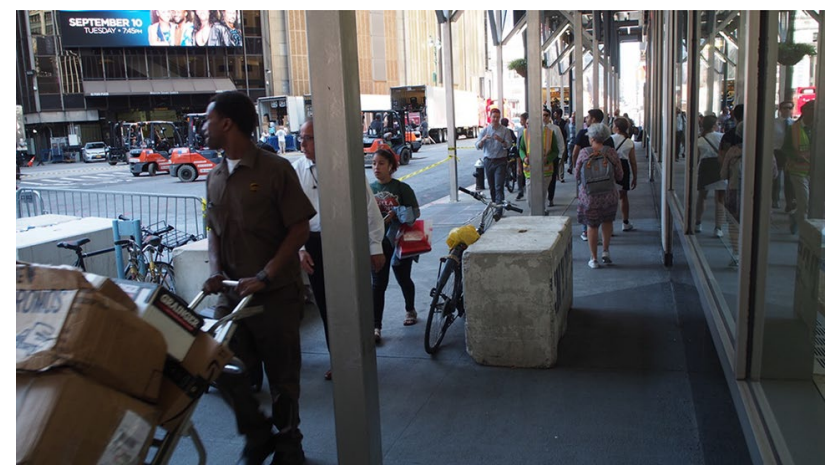

Fig. 11 Blocks on sidewalk in construction area, Penn Station

bollards (Butler and Bowlby 1997). ${ }^{4}$ These are larger concerns around access and openness which impact the quality of urban public spaces and which are important to consider now in the light of significantly increased securitization of public space sites such as sidewalks. It also requires a comprehensive revision of standards and codes which outline the minimum baseline requirements for access but do not consider broader perceptions of public space and their levels of comfort.

One area of conflict noted in all the interviews was with street vendors, especially since areas with large tourist flows targeted for securitization are also those most desirable for vendors. The interviewee from the Street Vendor Project, an advocacy organization, highlighted how bollards create conditions which, when combined with City regulations requiring vendors to locate at the edge of the curb, make it impossible for vendors to legally occupy sidewalks (SVP). Vendors even see bollard placement as a strategy used by local businesses to prevent their presence (PDC, SVP). Vendor groups are not always officially consulted during the planning and design stages for securitization projects, and often have to advocate for their legal presence on the city's redesigned sidewalk spaces (SVP).

In general, additional research is needed to measure the impacts of physical security devices on pedestrians and other public space users. Studies such as that by CPNI are typically based on highly controlled experiments rather than on real-time observations of real spaces. Not all of the impact is negative. We also observed people sitting on concrete blocks, standing on them to take photos, and other behaviors. Blocks, which are seen as temporary installations, seem more amenable to a range of behaviors than do bollards, but as the respondent from the NYPD noted, "it is New York, so I'm sure lots of people do all kinds of things."

\footnotetext{
${ }^{4}$ The authors have not as yet interviewed NYC advocacy groups for disabled people to more directly get their views on these interventions, but think it is important to do so.
}

\section{Designing for pedestrians and traffic safety}

As opposed to protecting individual buildings from VBIED's, protecting pedestrians from vehicle-ramming aligns with Vision Zero programs which have the goal of eliminating deaths and serious injuries in the transportation network. Some media accounts make this connection between securitization against vehicle ramming and Vision Zero (Freemark 2017; Gelinas 2018), but city staff did not do so in the interviews, nor do the City's Vision Zero documents and materials. There is also an institutional separation between securitization and Vision Zero approaches because they operate through different funding and procurement processes (DOT).

New York City's Vision Zero program, the first adopted in North America in 2014, consists of a bundle of efforts categorized as enforcement (mostly of speeding drivers), education, and engineering. Engineering approaches have the most potential to work with securitization goals by changing street designs to reduce vehicle speeds and creating safe pedestrian spaces. As part of the engineering component, the City has implemented more than 400 safety-related street improvements, including reconfiguring intersections and installing traffic calming features such as raised intersections, bollards, and refuge islands (City of New York 2019). Project locations are based on high rates of traffic-related pedestrian injuries and deaths. Many of these are located in automobile-oriented areas such as large arterials and boulevards in the outer boroughs and have little overlap with areas where securitization is currently prioritized (DOT). Much of Manhattan is also designated, however, where Vision Zero and securitization areas correspond.

The NYC Street Design Manual is another place the City could incorporate design guidance for securitization. First released in 2009, the manual was a ground-breaking document intended to be a 'comprehensive resource on street design guidelines, policies, and processes' (New York City \& Department of Transportation 2015). The city has just released the updated, third edition (New York City Department of Transportation 2020). It incorporates a number of goals, but safety is especially emphasized, part of which is to prioritize 'walking, cycling, use of mobility devices for those with disabilities, and other non-automotive modes' and to 'design streets for slower speeds to discourage speeding' (20). While there are major sections on the process of street projects, materials, and other topics, a large part of the manual is devoted to street 'geometry,' described as "a "toolbox" of street treatments that focus on safety, mobility and sustainability' (56) that describes different types of cycling facilities, sidewalk types, pedestrian plazas, and traffic calming strategies to divert and slow traffic. 

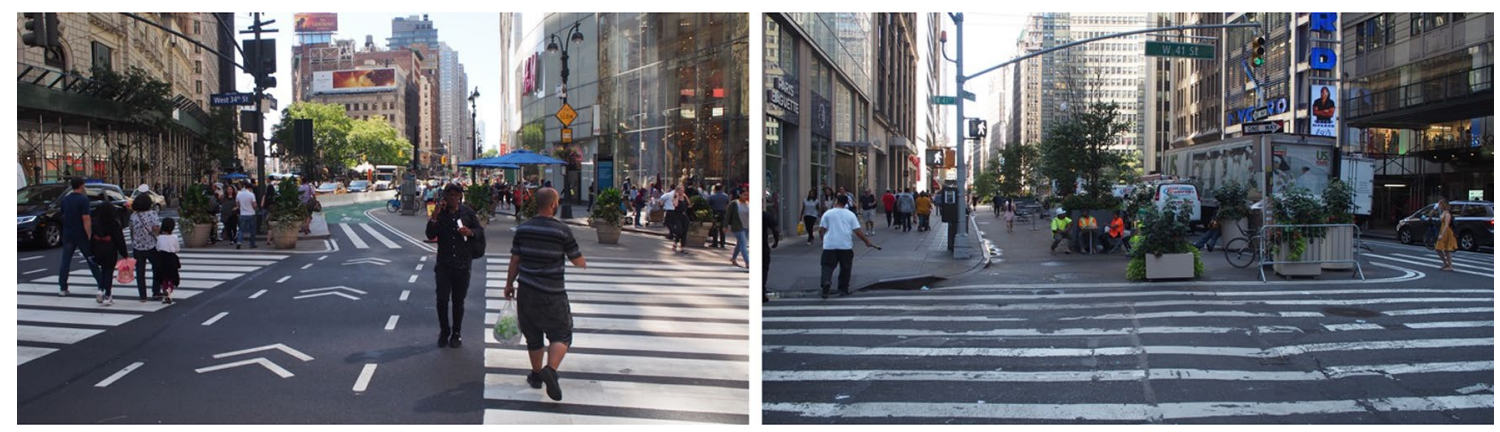

Fig. 12 Pedestrian plazas and bike lanes protected by concrete block installations, but with large openings, Herald Square (left) and Times Square at $41^{\text {st }}$ Street (right)
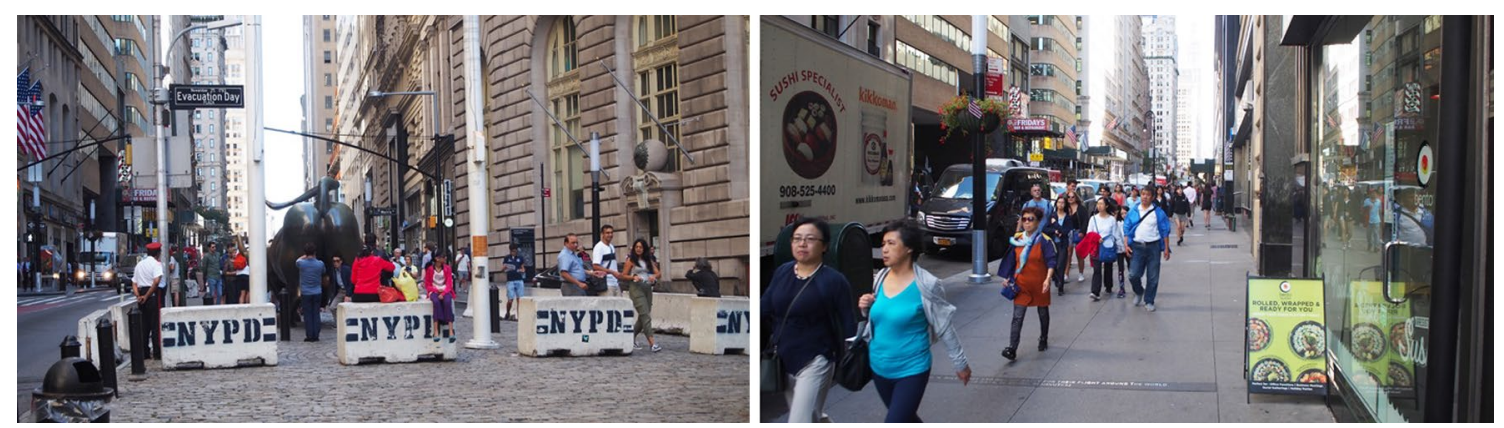

Fig. 13 Temporary concrete blocks around Charging Bull statue (left) and open sidewalks just a few meters north (right). Note that only the area around the statue has been securitized

The manual has little discussion of security as opposed to traffic safety, with the most extensive reference about protecting buildings, and not pedestrians and open spaces, 'from vehicle-borne explosives' (177). A few treatments such as pedestrian plazas refer to 'pedestrian security measures,' without further discussion or design guidance. On the ground, there is clear need for bringing securitization, pedestrian safety, and public open space concerns together. One of the most visible examples is along the series of pedestrian plazas that were created as part of the "Green light for Midtown" plan (New York City Department of Transportation 2010), where most have been securitized through the placement of concrete blocks in very uneven applications (Fig. 12). As noted in the PDC interview, the City may not have enough information to create prescriptive guidelines, but there is clear overlap and potential for further integration. Bollards, for example, as the most ubiquitous security device for ramming attacks, are prescribed in the Street Manual for pedestrian-safety islands, shared streets, and mid-block narrowings, but their general use needs to be further articulated.

\section{Discussion and conclusion}

While institutional path dependence and departmental siloes are resistant to change, the threat of vehicle-ramming attacks presents a unique opportunity for agencies to work together to create public spaces that are safe, secure, accessible, and open. Currently, while many agencies in NYC participate in the Interagency Security Infrastructure Working Group, the City primarily draws on the urban design tradition rooted in securing spaces from crime and terrorism. This is not to say that these agencies, including the NYPD's Counter-Terrorism Bureau, are not concerned with the accessibility and openness of the City's public spaces. Indeed, this concern was expressed by all interview respondents. Respondents, also, were generally looking for further design guidance. More surprisingly, there seemed to be little thought about how to integrate securitization with the urban design aimed at redesigning streets to increase pedestrianization and safety.

In comparison to protection from VBIEDs, vehicleramming attacks target urban crowds that are ubiquitous in most cities. In such cases, site selection for anti-terrorism security design becomes increasingly problematic, and there are debates about securitizing sites that 'don't have 


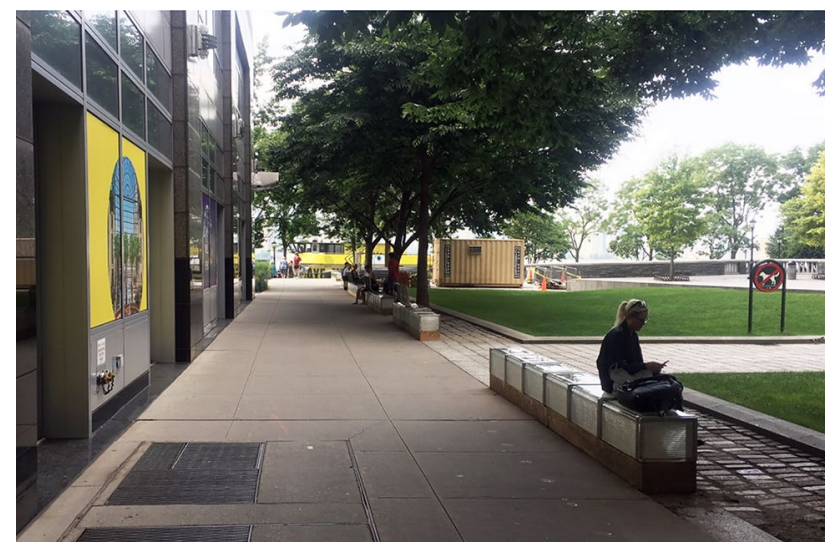

Fig. 14 Reinforced street benches, Battery Park City

much significance' as iconic or tourist sites, but are heavily used (DCP, NYPD). This dilemma is seen at a very local level where a high-profile site has been secured, but equally busy nearby sidewalks are vulnerable to a vehicle mounting the curb (Fig. 13). Vision Zero and other pedestrian-safety programs, on the other hand, are based on reliable and up-to-date data of traffic accidents and the resulting risks of clashes between automobiles, and pedestrians and bicyclists. The parameters for measuring risk for pedestrians overlap with that for vehicle-ramming attacks - the proximity of large groups of pedestrians to speeding vehicles. In such cases, aligning securitization planning efforts with pedestrian-safety programs based on empirical evidence can allow for a better-informed design process. Decision-making based on data can also help reduce fear mongering among residents and visitors to the site, thus helping reduce the fortress-like experience of public spaces.

Currently, as shown from the NYC case study, there is minimal intentional alignment between anti-terrorism security and traffic safety designs. However, their shared goal of managing the relationship between pedestrians and automobiles creates an opportunity for previously separate design operations to work together. Those involved with anti-terrorism programs can collaborate with transportation planning and design agencies to design barriers that are robust and protective while still allowing for a high level of publicness. Some projects such as Battery Park City (Fig. 14), described earlier in this paper have already experimented with such designs. There is also opportunity for the use of street designs that limit vehicle speeds, reducing their potential for harm, and increasing pedestrian safety and comfort.

Additionally, while security remains a critical need for the city's public spaces, accessibility should also be a key goal in their design. The ad hoc implementation of bollards potentially reduces access to spaces for vulnerable groups such as wheelchair users, the visually-impaired, and street vendors, and contributes to pedestrian bottlenecks. Accessibility concerns have typically fallen within the purview of transportation planners and urban designers, both of whom can contribute greatly to better site design for securitization. Additionally, as bollards become commonplace in NYC's open public spaces, it is essential that other city guidelines, such as those governing vendor locations, be updated to reflect the new sidewalk configurations. This requires interdepartmental collaboration.

The New York City case study illustrates the various institutional planning processes and urban design strategies that have been deployed in the last few years in response to the threat of vehicle-ramming attacks. By using vehicles as weapons themselves, ramming attacks differ from previous terrorist strategies that used vehicles to deliver explosives to symbolic buildings. Ramming attacks are thus directed against public space itself, and this raises new questions for urban design. The security response to ramming attacks, however, draws design lessons largely from a tradition of protecting hard targets such as symbolic buildings from vehicles delivering explosives, along with CPTED strategies. While ramming attacks challenge established ideas about pedestrians, automobiles, and street and public space design, design strategies related to pedestrian-safety programs such as Complete Streets and Vision Zero operate in a separate institutional and conceptual sphere. While these recent street design efforts emphasize openness and accessibility, responses to ramming attacks emphasize security and separation over openness. Recent violence against Black Lives Matter activists in the United States using vehicle ramming have reminded us that it is important to create public spaces, especially streets, that are designed simultaneously for security and openness (Hauck 2020). There is considerable overlap in the site selection and physical design approaches between securitization and street design programs. Reconsidering the strict boundaries that exist between them both conceptually and institutionally is a first step towards designing public spaces and streets that are open, accessible, livable, and secure.

Acknowledgements The authors thank the interview respondents for agreeing to participate in this research and giving their valuable time to this effort.

Funding This work was supported by the Social Sciences and Humanities Research Council of Canada under Grant 72050335. The funding source had no specific involvement in the research project.

\section{Declarations}

Conflict of interest None. 


\section{References}

Aradau, C. 2015. 'Crowded places are everywhere we go': Crowds, emergency, politics. Theory, Culture \& Society 32 (2): 155-175. https://doi.org/10.1177/0263276414562429.

Beck, U. 2002. The terrorist threat: World risk society revisited. Theory, Culture \& Society 19 (4): 39-55. https://doi.org/10. $1177 / 0263276402019004003$.

Benton-Short, L. 2007. Bollards, bunkers, and barriers: Securing the national mall in Washington, DC. Environment and Planning D: Society and Space 25 (3): 424-446. https://doi.org/10. 1068/d2405.

Bird, M. 2017, March 24. Terror in London: Attack highlights big cities' challenge-Cities around the world have erected barriers at government and tourist sites. Wall Street Journal, Europe; Brussels, A.4.

Boddy, T. 2007. Architecture emblematic: Hardened sites and softened symbols. In Indefensible space: The architecture of the national insecurity state, 1st ed., ed. M. Sorkin, 277-304. Milton Park: Routledge.

Bugliarello, G. 2003. Urban security in perspective. Technology in Society 25 (4): 499-507. https://doi.org/10.1016/j.techsoc.2003. 09.004 .

Burke, J. 2018, January 29. Cities and terror: An indivisible and brutal relationship. The Guardian. https://www.theguardian. com/cities/2018/jan/29/cities-terror-attacks-brutal-relationsh ip-terrorism

Butler, R., and S. Bowlby. 1997. Bodies and spaces: An exploration of disabled people's experiences of public space. Environment and Planning d: Society and Space 15 (4): 411-433. https://doi. org/10.1068/d150411.

Chambers, P., and T. Andrews. 2019. Never mind the bollards: The politics of policing car attacks through the securitisation of crowded urban places. Environment and Planning D: Society and Space 37 (6): 1025-1044. https://doi.org/10.1177/0263775818824343.

City of New York. 2019. Borough pedestrian safety action plans: Vison zero update (p. 142).

Clarke, C. P. 2017, August 18. When the car is a terror weapon, can we prepare for attacks? https://www.rand.org/blog/2017/ 08/when-the-car-is-a-terror-weapon-can-we-prepare-for.html

Coaffee, J. 2013a. Towards next-generation urban resilience in planning practice: From securitization to integrated place making. Planning Practice \& Research 28 (3): 323-339. https://doi.org/ 10.1080/02697459.2013.787693.

Coaffee, J. 2013b. Rescaling and responsibilising the politics of urban resilience: From national security to local place-making. Politics 33 (4): 240-252. https://doi.org/10.1111/1467-9256.12011.

Coaffee, J. 2017, June 22. Urban terrorism isn't going to stop. Can city planners help reduce its lethal impact? Washington Post. https://www.washingtonpost.com/news/posteverything/wp/ 2017/06/22/urban-terrorism-isnt-going-to-stop-can-city-plann ers-help-reduce-its-lethal-impact/

Coaffee, J., P. O'Hare, and M. Hawkesworth. 2009a. The visibility of (In)security: The aesthetics of planning urban defences against terrorism. Security Dialogue 40 (4-5): 489-511. https://doi.org/ 10.1177/0967010609343299.

Coaffee, J., D.M. Wood, and P. Rogers. 2009b. The everyday resilience of the city: How cities respond to terrorism and disaster. London: Palgrave Macmillan.

Corporate Risk Services. 2019. Intelligence bulletin: Vehicular terrorism. The threat behind the wheel. G4S North America.

Counter Extremism Project. 2019. Vehicles as weapons of terror. Counter Extremism Project.

Cozens, P., and T. Love. 2015. A review and current status of crime prevention through environmental design (CPTED). Journal of
Planning Literature 30 (4): 393-412. https://doi.org/10.1177/ 0885412215595440.

Dangerfield, K. 2018, April 25. Deadly vehicle attacks: What can other cities teach Toronto about protecting pedestrians?|Globalnews.ca. Global News. https://globalnews. ca/news/4166803/toronto-van-attack-security-pedestrian-barri er/

Deukmedjian, J.E. 2013. Making sense of neoliberal securitization in urban policing and surveillance. Canadian Review of Sociology/ revue Canadienne De Sociologie 50 (1): 52-73. https://doi.org/ $10.1111 /$ cars. 12002 .

Eisinger, P. 2004. The American City in the age of terror: A preliminary assessment of the effects of September 11. Urban Affairs Review 40 (1): 115-130. https://doi.org/10.1177/1078087404 268761.

Engineering security. Protective design for high risk buildings. 2009. New York City Police Department. https://www1.nyc. gov/assets/nypd/downloads/pdf/nypd_engineeringsecurity.pdf

Farish, M. 2004. Another anxious urbanism: Simulating defense and disaster in cold war America. In Cities, war, and terrorism: Towards an urban geopolitics, ed. S. Graham, 93-109. Wiley.

FEMA 430, site and urban design for security: Guidance against potential terrorist attacks. 2007. Federal Emergency Management Agency. https://www.fema.gov/media-library/assets/ documents/12746

Freemark, Y. 2017, November 3. Opinionlhow safer streets can thwart terrorists. The New York Times. https://www.nytimes. com/2017/11/03/opinion/terrorism-transportation-infrastruc ture.html

Gaffikin, F., M. Mceldowney, and K. Sterrett. 2010. Creating shared public space in the contested city: The role of urban design. Journal of Urban Design 15 (4): 493-513. https://doi.org/10.1080/ 13574809.2010 .502338 .

GCDN. 2018. Beyond concrete barriers. Innovation in urban furniture and security in public space (p. 71). Global Cultural Districts Network. https://gcdn.net/wp-content/uploads/2018/01/GCDNUrban-Furniture-Study-A4-FINAL-highres_web.pdf

Gelinas, N. 2018, October 17. There's a fatal flaw in anti-terror infrastructure. CityLab. https://www.citylab.com/perspective/2018/10/ vehicular-terrorism-age-vision-zero/573229/

Gold, J. R., and G. Revill (Eds.). 2000. Landscapes of defence. Prentice Hall.

Goldstein, J. 2018, July 16. City will place 1,500 bollards to counter vehicle attacks. The New York Times. https://www.nytimes.com/ 2018/01/02/nyregion/city-will-place-1500-bollards-to-countervehicle-attacks.html

Grabar, H. 2017, August 30. Our best defense against vehicular terrorism can also be beautiful. Slate Magazine. https://slate.com/ news-and-politics/2017/08/bollards-are-our-best-defense-again st-the-use-of-vehicles-as-weapons.html

Graham, S., ed. 2004. Cities, war, and terrorism: Towards an urban geopolitics. New York: Wiley.

Hauck, G. 2020, July 9. "I would be very careful in the middle of the street”: Drivers have hit protesters 66 times since May 27. USA TODAY. https://www.usatoday.com/story/news/nation/2020/07/ 08/vehicle-ramming-attacks-66-us-since-may-27/5397700002/

Hebbert, M. 2005. Engineering, urbanism and the struggle for street design. Journal of Urban Design 10 (1): 39-59. https://doi.org/ 10.1080/13574800500062361.

Hess, P.M. 2009. Avenues or arterials: The struggle to change street building practices in Toronto, Canada. Journal of Urban Design 14 (1): 1-28. https://doi.org/10.1080/13574800802451049.

Hess, P., K. Gregg, and R. Whitney. 2019. Modernism, pedestrians, and public space. In T. Banerjee and A. Loukaitou-Sideris (Eds.), The new companion to urban design. Routledge Handbooks Online. https://doi.org/10.4324/9780203731932-61 
Hollander, J.B., and C. Whitfield. 2005. The appearance of security zones in US cities after 9/11. Property Management 23 (4): 244256. https://doi.org/10.1108/02637470510618398.

Ishaque, M.M., and R.B. Noland. 2006. Making roads safe for pedestrians or keeping them out of the way?: An historical perspective on pedestrian policies in Britain. The Journal of Transport History 27 (1): 115-137. https://doi.org/10.7227/TJTH.27.1.8.

Jasiński, A. 2018. Protecting public spaces against vehicular terrorist attacks. Czasopismo Techniczne, 2018(Volume 2), 47-56. https:// doi.org/10.4467/2353737XCT.18.019.7992

Jeffery, C. 1971. Crime prevention through environmental design. Sage. https://www.ncjrs.gov/App/Publications/abstract.aspx?ID=10719

Kaleta, P. 2018, August 15. London mayor wants to ban cars in some areas after attack. Politico. https://www.politico.eu/article/ london-mayor-wants-to-ban-cars-in-some-areas-after-attack/

Lazo, L. 2018, February. Nation's capital overhauls parking restrictions to guard against terror attacks. Washington Post. https:// www.washingtonpost.com/news/dr-gridlock/wp/2018/02/27/ nations-capital-overhauls-parking-restrictions-to-guard-againstterror-attacks/

Little, R.G. 2004. Holistic strategy for urban security. Journal of Infrastructure Systems 10 (2): 52-59. https://doi.org/10.1061/(ASCE) 1076-0342(2004)10:2(52).

Low, S.M. 2006. The erosion of public space and the public realm: Paranoia, surveillance and privatization in New York City. City \& Society 18 (1): 43-49. https://doi.org/10.1525/city.2006.18.1.43.

Marcuse, P. 2006. Security or safety in cities? The threat of terrorism after 9/11. International Journal of Urban and Regional Research 30 (4): 919-929. https://doi.org/10.1111/j.1468-2427. 2006.00700.x.

Miller, V., and K.J. Hayward. 2019. 'I did my bit': Terrorism, tarde and the vehicle ramming attack as an imitative event. The British Journal of Criminology 59 (1): 1-23. https://doi.org/10.1093/ bjc/azy017.

Németh, J., and J. Hollander. 2010. Security zones and New York City's shrinking public space. International Journal of Urban and Regional Research 34 (1): 20-34. https://doi.org/10.1111/j. 1468-2427.2009.00899.x.

New York City Department of Transportation. 2010. Green light for midtown evaluation report. New York City Department of Transportation.

New York City \& Department of Transportation. 2015. Street design manual, updated, 2nd edition (p. 264).

New York City Department of Transportation. 2020. Street design manual, 3rd edition (p. 318).

Newman, O. 1973. Defensible space; Crime prevention through urban design. New York: Macmillan Pub Co.
Nishiyama, H. 2018. Crowd surveillance: The (in)securitization of the urban body. Security Dialogue 49 (3): 200-216. https://doi.org/ 10.1177/0967010617741436.

Reliance Foundry. 2017. K-rated bollards. Reliance Foundry Co. Ltd. https://www.reliance-foundry.com/blog/k-rated-bollards

Reporters, T. 2018, August 14. From Westminster to nice: Vehicle rampage attacks in UK and Europe. The Telegraph. https://www. telegraph.co.uk/news/0/westminster-nice-vehicle-rampage-attac ks-uk-europe/

Rosenberg, E., and L. Stack. 2017, May 18. One dead and 22 injured as car rams into pedestrians in times square. The New York Times. https://www.nytimes.com/2017/05/18/nyregion/times-squarecrash.html

Sadik-Khan, J., and S. Solomonow. 2017. Streetfight: Handbook for an urban revolution (Reprint edition). Penguin Books.

Savitch, H. V. (2008). Sketching urban terrorism. In Cities in a Time of Terror: Space, Territory, and Local Resilience (pp. 3-25). Routledge.

Sawyer, P. 2018, June 28. Wimbledon "ring of steel" goes up as police chief warns vehicle terror attacks are continuing threat. The Telegraph. http://search.proquest.com/docview/2061221119/citation/ 49EAAF3C41F44DFEPQ/1

Shaver, K. 2018, September 6. Cities are using design to thwart terror attacks-From benches to plantersithe independent. The Independent. https://www.independent.co.uk/life-style/design/antiterror-city-architecture-planning-benches-public-spaces-a8524 071.html

The national capital urban design and security plan (p. 96). 2002. National Capital Planning Commission.

The site security design guide (p. 153). 2007. U.S. General Services Administration, Public Buildings Service.

Toure, M. 2017, December 20. NYC council moves sidewalk bollards bill to prevent terror attackslobserver. The Observer. https://obser ver.com/2017/12/nyc-sidewalk-bollards-terror-attacks/

Vale, L. 2005. Securing public space. Places Journal, 17(3). https:// placesjournal.org/article/securing-public-space/

Vehicles as weapons of terror. 2017, May 22. Counter extremism project. https://www.counterextremism.com/vehicles-as-weapo ns-of-terror

Wilson, J.Q., and G.L. Kelling. 1982. The police and neighbourhood safety: Broken windows. The Atlantic Monthly 3 (2): 29-38.

Publisher's Note Springer Nature remains neutral with regard to jurisdictional claims in published maps and institutional affiliations. 